\title{
Is Albania Ready for a New Media Model?
}

\author{
Ana Rafti \\ Lecturer in the department of Communication and Public Relations, \\ Faculty of Social Science at the European University of Tirana.
}

\section{Doi:10.5901/ajis.2013.v2n2p485}

\begin{abstract}
Albania inherited a media system with only a handful of state-owned media outlets controlled austerely by the communist party-state. Actually the political system and the society as a whole, and particularly, the media landscape have changed dramatically. Despite the variety of choices the numerous media outlets might seem to offer to a wider public audience, a series of factors, - including the lack of proper journalistic education, political polarization, and still a weak economy and relatively small media market - have hampered the development of a professional media system in Albania, which fails to measure up to any of the key dimensions of well-established western media models. Our analysis is largely based on the most important dimensions that might characterize (and influence) Albanian media systems, more specifically, the Albanian media system, in light of Hallin and Mancini's (2004) work on comparative political communication. In view of their four key dimensions on media models analysis, Albanian press system clearly lags behind the indicators of most of the countries reviewed, especially in terms of its very low press circulation and readership figures, the severe financial burdens it is faced with; Albania press system clearly lags behind the indicators of most of the countries reviewed, especially in terms of its very low press circulation and readership figures, as well as the severe financial burdens it is faced with; Albanian news media fail in meeting adequate journalistic education and proper training standards; Albania is apparently needing to adopt a new model that could curb the Government's and state's potential intervention and attempts to control information. We would argue that Albania is closer to the model named 'the Mediterranean,' or 'the Polarized Pluralistic Model,' which relates to media systems in Italy, Spain, Greece, Portugal and France and we believe that it would be very interesting to explore whether adopting such a model would be a better solution for Albania's media system.
\end{abstract}

\section{Introduction}

Following the collapse of one of the most prolonged (1944-1990) isolationist and totalitarian regimes in Eastern Europe in the early 1990s, Albania inherited a media system with only a handful of state-owned media outlets controlled austerely by the communist party-state, "which used them as tools of indoctrination" (HRW, 2002). As the country follows a rather troubled and challenging path of transition from totalitarianism and severe isolation to democracy and rule of law, the political system and the society as a whole, and particularly, the media landscape have changed dramatically. The early1990s saw a striking proliferation of an array of press outlets of a diverse range in breadth and scope, followed in the second half of the decade by the gradual development of a privately-run radio and television industry. Surprisingly, considering the market size and potential of a country with roughly 3.2 million people (INSTAT, 2002), Albania has reportedly some 257 media outlets currently, including television and radio stations (OSI, 2005).

However, despite the variety of choices these numerous media outlets might seem to offer to a wider public audience and their important contributions to the political and public debate, in this essay, I argue that a series of factors, including the lack of proper journalistic education, political polarization, and a still a weak economy and relatively small media market - have hampered the development of a professional media system in Albania, which fails to measure up to any of the key dimensions of well-established western media models as we know it.

The framework of this essay's analysis is largely based on the most important dimensions that might characterize (and influence) national media systems, more specifically, the Albanian media system, in light of Hallin and Mancini's (2004) work on comparative political communication. Hallin and Mancini's analysis of media models derives from the study of media systems in North Atlantic and most Western European countries, with special attention to their historical origins and development. The four key dimensions suggested by Hallin and Mancini are: (1) the degree and shape of development of media markets, with particular emphasis on the newspaper press and the mass circulation press; (2) a variable of 'political parallelism' or the degree and nature of links between political parties and the media and more generally the extent to which media reflect political divisions; (3) the degree (and direction) of development of journalistic professionalism; and (4) the degree and nature of state intervention in the media system. As follows, I will apply and 
analyze the above four dimensions in Albania's situation of news media in an attempt to evaluate and, possibly, categorize Albania's media system within any of the three models of 'media and political system' as identified by Hallin and Mancini (Ibid.).

\section{The Development of media markets, circulation press}

Despite the significant changes in the media landscape over the last 18 years (1990-2008) of a country newly-introduced to the practices of a pluralistic society and a free market economy, yet, the media industry remains far from being a viable and developed market. For instance, although individual press circulation statistics are not publicly available, the total annual circulation figure for an estimated total of more than 200 publications available (including daily and weekly newspapers, magazines, newsletters, and pamphlets), amounts reportedly to 30 million, while the combined daily circulation figure for some 19 nationwide news dailies remains well below 60,000 in total (Source: Albanian Media Institute). As some researchers argue, the "highly rhetorical and biased press" might well be one of the main reasons that have apparently "disenchanted readers and led to shrunken circulation numbers," (HRW, 2002, p. 10) for many of the publications.

In addition, the low readership figures, declining subscription rates and selling figures, can also be attributed to "a malfunctioning distribution system and poor infrastructure" (EU, 2008, p. 13), as well as the "high production costs" (HRW, 2002) of a press industry, which appears unable to serve large parts of the country that struggles at the very early stages of establishing a market economy.

Furthermore, given the reportedly small advertising market, market experts would expect many of these print news outlets to go bankrupt. However, as these print news media cannot simply survive on the ad revenues they are able to generate alone so far, many of them choose to rely on subsidies by their owner's other successful business, as found in the latest of a series of reports issued by a Washington-based media development agency (IREX, Media Sustainability Index, 2008), while many others remain understaffed and operate with very limited resources.

Therefore, on the first dimension of Hallin and Mancini's analysis of media models, that is the degree and shape of development of media markets, Albania press system clearly lags behind the indicators of most of the countries reviewed, especially in terms of its very low press circulation and readership figures, as well as the severe financial burdens it is faced with, which are closely related to the current stage of its social and economic development.

\section{Political parallelism}

For a better understanding of the news media, Hallin and Mancini look at "the nature of the state, the system of political parties, the pattern of relations between economic and political interests, and the development of civil society, among other elements of social structure" (Hallin and Mancini, 2004, p. 8), and among other political system variables, they introduce also "the distinction between moderate and polarized pluralism" (p. 65), in which I will use as a tool in my analysis of Albanian press's level of political parallelism.

As many observers have repeatedly noted, the rivalry of Albania's political parties at both ends of the political spectrum "has frequently been intense, based on a mutual lack of trust, and at times antagonistic," which, "in recent years has caused political deadlocks, often resolved through facilitation by international institutions." (ODIHR, 2005, p. 3). Amid this climate of heightened political polarization, although the news media in Albania reflect a diversity of viewpoints, major key outlets of significant reach and audience continue to display "an evidently partisan editorial line and harsh criticism" (p. 16) in support of one political faction or another.

Furthermore, print outlets often have explicit ties to political parties or other interest groups $(\mathrm{FH}, 2008)$ acting oftentimes as a private lobby for friendly politicians, in what is commonly referred to in Albania as the so-called Berlusconi ${ }^{1}$ syndrome, - i.e., closely maintained connections between media entities, business interests and politicians, which may limit media's independence and reinforce editorial control. And, as a matter of fact, the intermingling of

${ }^{1}$ Silvio Berlusconi, a successful entrepreneur and media tycoon, is the second longest-serving Italian prime minister , a position he has held on four separate occasions: from 1994 to 1995, from 2001 to 2005, from 2005 to 2006, currently since 2008. Berlusconi's extensive control over the media has been widely criticized by different analysts and press freedom organizations, who allege Italy's media has limited freedom of expression (David, 2002,. pp291-307). 
business, political and media interests still continues to affect the development of independent media in Albania as "there is no effective legislation to ensure transparency of media ownership and funding" (EU, 2008, p. 10).

In view of Hallin and Mancini's second dimension of the media system, or political parallelism, Albanian media are only a mere reflection of the political and social structure out of which they emerge, failing "to have an impact of their own" (p. 8) on those same political and social structure, and serve a wider public interest.

\section{The development of journalistic professionalism}

Reviewing Hallin and Mancini's third dimension of a media system, that is the degree of development of journalistic professionalism in Albania's media setting, it goes without saying that the University of Tirana is the only higher learning public institution that offers courses on media related careers, with its Department of History and Philology offering a degree in journalism, which was established only in the early 1990s.

An extensive study conducted by the Albanian Media Institute in 2000, surveying a total of 1,366 journalists employed in Albanian media outlets, found that only $8.2 \%$ of them held a B.A. degree from the Department of Journalism, while the figure of those who had completed any postgraduate education (usually not related to journalism or communication studies) was as low as 0.07 percent, and those who had completed only secondary education amounted to 0.06 percent (MPI, 2001, p. 2). The latest figure tended to be higher for local small-size media outlets outside Tirana, which, in most cases run very small newsrooms and work with very limited staff and resources.

Apart from the above-reported lack of proper education and professional training for journalists, most journalists in Albania work without legal labour contracts, "adding to job insecurity and encouraging self-censorship" (FH, 2008). Furthermore, professionalism practices followed by Albanian media outlets fell short of meeting internationally-accepted standards of the media industry's self-regulation, such as the adoption of a code of ethics. Even though some of the major journalist associations have recently agreed on adopting a voluntary code of ethics, yet, it is rarely enforced by most of the media outlets' managing editors (Londo, 2005).

With regards to Hallin and Mancini's third dimension of the media system, or the development of journalistic professionalism, Albanian news media fail in meeting adequate journalistic education and proper training standards, as well as suffer from other working practice principles, such as the application of labor contracts and the adoption of a widely-accepted code of ethics.

\section{The degree and nature of state intervention in the media system}

Finally, Hallin and Mancini identify as the fourth dimension in their analysis of media systems, the degree and nature of state intervention in the media system.

The media industry in Albania has currently gone past the early stage of its development, as it had to defend itself against the Government attempts to control information. Instead, policy experts stress that "even when it is politically motivated, interference with the media is exerted through economic means, such as the allocation of State advertising and Government support or obstruction of the proprietors' other business activities" (OSI, TV 2008, p. 10). As many would agree, most of the present conflicts between the Government and state institutions on the one side, and the media on the other are caused by economic, rather than political, interests - even though, there are reportedly sporadic cases of the current government putting selective pressure on opposition-oriented media recently².

In Albania's case, this becomes even more pressing, given the relative shortage of advertising revenues and the relatively large volume of state advertising ${ }^{3}$ or government subsidies ${ }^{4}$, which is comparable in value to the entire private

\footnotetext{
2 In July 2007, authorities sought to impose a 12 million euro (\$16.6 million) fine on Top Media for unpaid taxes, prompting objections and demonstrations by civil rights and press freedom groups (Freeedom House, 2008).

${ }^{3}$ A study conducted by the Human Rights Watch, a New York-based media freedom watchdog, found that Albanian "ministers and other senior officials use their own share of advertising leverage to retaliate against criticism of their personalperformance or of their respective institution" (HRW, 2002, p. 13).

${ }^{4}$ Government subsidies - which, are usually shaped as compensation for carrying massive public awareness advertisements - are viewed by media experts as a source of concern for media freedom and media independence in Albania. They stress that "[w]hile it is up to each media outlet to accept or refuse such subsidies, only an independent body and transparent procedures could ensure their fair and non-intrusive allocation" (HRW, 2002, p. 13).
} 
sector advertising, and it ultimately "gives the Albanian government significant financial leverage over the press. In the absence of effective control mechanisms, that unchecked financial power is abused for purposes of political and personal profit." (HRW, 2002, p. 13).

Therefore, even the last dimension in Hallin and Mancini's analysis, that is the degree and nature of state intervention in the media system, Albania is apparently needing to adopt a new model that could curb the Government's and state's potential intervention and attempts to control information.

\section{Conclusions}

In my essay I attempted to apply and analyze Albania's media system, in view of Hallin and Mancini's analysis of media models based on the four dimensions identified by the authors and described above. Although, this does not meet the rigors of an empirical study, Albania shows an unambiguous differentiation on all dimensions, hitting low on all possible evaluations. In terms of the dimensions and concepts mentioned, Albania's model is generally characterized by late and incomplete development of the press and weak journalistic professionalism, strong elements of antagonistic political parallelism and an interventionist role of state, with a fairly recent history in some cases of authoritarian rule and much evidence of clientelism.

Given the countries' differentiation in Hallin and Mancini's evaluation scale, especially their geographical covariation between media structures on one hand and political and economic structures on the other, I would argue that Albania is closer to the second model named 'the Mediterranean,' or 'the Polarized Pluralistic Model,' which relates to media systems in Italy, Spain, Greece, Portugal and France. As the authors argue about state intervention being more common in the former two models - that is the Polarized Pluralist Model and the Democratic Corporatist Model, - and the news media categorized in the third one, the Liberal Model, being more market-oriented than the rest and thus, having traditionally been more likely to set the agenda of political communication than the news media in the Mediterranean and Northern European countries, I believe that it would be very interesting to explore whether adopting such a model would be a better solution for Albania's media system, and if so, what are the chances of success, or failure.

\section{References}

Hallin, D. C., \& Mancini, P. (2004). Comparing Media Systems: Three Models of Media and Politics. Cambridge, UK: Cambridge University Press.

Human Rights Watch (June, 2002). Albania, The Cost of Speech: Violations of Media Freedom in Albania. Vol. 14, No. 5 (D).

McQuail, D. (2005). Book review: Daniel C. H., and Paolo Mancini (2004). Comparing Media Systems: Three Models of Media and Politics. Cambridge: Cambridge University Press. European Journal of Communication 20(2); pp. 266-268, Sage Publications.

Jones M., T. (2008). Book review: Daniel C. H., and Paolo Mancini (2004). Comparing Media Systems: Three Models of Media and Politics. Cambridge: Cambridge University Press. Comparative Political 41(1) January 2008: 128-13.8.Sage Publications.

Londo, I. (2005). Media: The Business of Ethics, the Ethics of Business. South East European Network for Professionalisation of the Media, Center for Independent Journalism, Bucharest, Romania.

International Research and Exchange Board (IREX), Media Sustainability Index 2008 - Albania (Washington, D.C.; IREX, 2008).

EU 2008 Progress Report on Albania, available at: <http://ec.europa.eu/enlargement/pdf/key document/2008/oct/albania progress reports en.pdf.>

Albanian Institute of Statistics (INSTAT), Popullsia e Shqipërisë 2001, (Population of Albania 2001). Tirana; INSTAT, 2002.

Open Society Institute. (2008). Television Across Europe: Follow-up Reports 2008. OSI/EU Monitoring and Advocacy Program, 2008 (EUMAP) - Network Media Program (NMP). Budapest. Q.E.D. Publishing.

Office for Democratic Institutions and Human Rights. (3 November 2005). Parliamentary Elections - Republic of Albania. OSCE/ODIHR Election Observation Mission Report, Warsaw.

Bejtia, A., Londo, I. and Doksani, A. (2001). Education of Journalists in Albania. Media Online, 2001 - Media Plan Institute, Sarajevo.

David, H. (2002). Silvio Berlusconi, i media e il conflitto di interesse. Bellucci and Bull (eds.), Politica in Italiana Edizione 2002, II Mulino, Bologna.

Freedom House: Map of Press Freedom - Albania 2008, available at: <http://www.freedomhouse.org /template.cfm?page $=251 \& y e a r=2008>$ 